\title{
'Not dead but sleeping': Expanding international law to better regulate the diverse effects of ceasefire agreements
}

\author{
Marika Sosnowski* \\ German Institute for Global and Area Studies (GIGA), Neuer Jungfernstieg 21, 20354 Hamburg, Germany \\ Email: ms@marikasosnowski.com
}

\begin{abstract}
Ceasefire agreements are legally governed by international humanitarian law because they have generally been considered in relation to how they affect levels of violence. However, new research in the fields of anthropology, security, and development studies suggests that ceasefires can have many more ramifications. These range from their ability to influence governance institutions, property and citizenship rights, economic networks, and security mechanisms. Consequently, this article suggests that a broader legal framework is needed through which to consider ceasefires and their consequences. While canvassing the option of ceasefires being types of contractual documents or as special agreements under Common Article 3 of the Geneva Conventions, the article concludes that the best way to regulate ceasefire agreements is through an expanded version of lex pacificatoria. Rather than being governed by hard international law, such a move would allow for the implementation of more flexible programmatic standards to influence the myriad ways ceasefires are negotiated, the conduct of belligerents, and their diverse effects on the ground during wartime.
\end{abstract}

Keywords: ceasefire agreements; civil war; international humanitarian law; lex pacificatoria; peace agreements

\section{Introduction}

In recent years there has been much debate and discussion about the legal dimensions of peace agreements. ${ }^{1}$ However, less attention has focused on what has conventionally been seen as their temporal precursor - ceasefires. While some scholars have canvassed the legal status of ceasefire agreements in relation to their use by the $\mathrm{UN}^{2}$ the general consensus seems to be that ceasefire agreements concluded in armed conflicts prior to a definitive ceasefire or peace agreement are governed by jus in bello (otherwise known as international humanitarian law) because, as Hugo Grotius puts it, when a ceasefire is signed the legal state of war is 'not dead but sleeping' ${ }^{3}$

${ }^{*}$ I would like to thank the organizers and participants of the La Trobe International Legal Studies Research Group Symposium for offering their insight and expertise on an earlier version of this article. Additionally, Marnie Lloydd for her support, knowledge, generosity, and keen eye.

${ }^{1}$ See, e.g., C. Bell, 'Peace Agreements: Their Nature and Legal Status', (2006) 100 American Journal of International Law 2; C. Stahn, J. S. Easterday and J. Iverson (eds.), Jus Post Bellum (2014); A. Solomou, 'Comparing the Impact of the Interpretation of Peace Agreements by International Courts and Tribunals on Legal Accountability and Legal Certainty in Post-Conflict Societies', (2014) 2 Leiden Journal of International Law 2.

${ }^{2}$ C. Henderson and N. Lubell, 'The Contemporary Legal Nature of UN Security Council Ceasefire Resolutions', (2013) 26 Leiden Journal of International Law 2; D. M. Morriss, 'From War to Peace: A Study of Cease-Fire Agreements and the Evolving Role of the United Nations', (1995) 36 Virginia Journal of International Law 801.

${ }^{3} \mathrm{H}$. Grotius, On the Rights of War and Peace: An Abridged Translation by William Whewell (2005), 434.

\footnotetext{
(c) Foundation of the Leiden Journal of International Law 2020. This is an Open Access article, distributed under the terms of the Creative Commons Attribution licence (http://creativecommons.org/licenses/by/4.0/), which permits unrestricted re-use, distribution, and reproduction in any medium, provided the original work is properly cited.
} 
As such, authors remain ambiguous about the legal nature or legal effects of ceasefire agreements because they are concluded in an environment where the laws of war continue to apply. In this paradigm, a ceasefire agreement itself or a breach of a ceasefire does not have any legal consequences in and of itself because the ceasefire agreement only suspends hostilities without ending the legal state of war. ${ }^{4}$

This means that ceasefires have generally been thought of as the first step on the teleological bridge between war and peace, i.e., as a quasi-interregnum between jus in bello and jus post bellum, but remain firmly anchored in the jus in bello space. However, more recent literature in the fields of anthropology, security, and development studies has considered how areas beyond violence can also potentially be influenced by ceasefire agreements. ${ }^{5}$ This literature holds that ceasefires are, therefore, not solely military tools, but can be used by warring sides as part of their larger political projects to renegotiate access and control over important resources such as governance institutions, ${ }^{6}$ citizenship and property rights, ${ }^{7}$ economic networks, ${ }^{8}$ and security mechanisms. ${ }^{9}$ These authors argue that ceasefires are not 'an end to or break in the fighting, whether or not it represents the final end of the war', ${ }^{10}$ rather the fact that a ceasefire agreement is negotiated and codified in the form of the text of the ceasefire agreement can be seen as a way of formalizing the relative power relations between the parties at a certain point in time and has the ability to activate rivalries and machinations for control, and create opportunities for a range of actors. While parties to an armed conflict already exist in a legal relationship via international humanitarian law, humanitarian law is most concerned with regulating the use of violence and the protection of civilians. It, therefore, does not provide adequate regulation for the more political consequences of ceasefires such as how they may affect governance institutions, ${ }^{11}$ economic networks, ${ }^{12}$ citizenship and property rights, ${ }^{13}$ or control over diplomatic and security mechanisms. ${ }^{14}$ This means that relying solely on the current way international humanitarian law is applied to civil wars to regulate how ceasefire agreements are negotiated and their effects is unsatisfactory.

To augment the efficacy of a ceasefire, there has been some consideration in the literature, albeit brief, of how ceasefires could be considered a type of contractual document or how certain terms of ceasefire agreements could form part of 'special agreements' under Common Article 3 of the Geneva Conventions. ${ }^{15}$ However, the limited number and depth of these arguments perhaps

${ }^{4}$ A. Lang, "Modus Operandi” and the ICJ's Appraisal of the Lusaka Ceasefire Agreement in the Armed Activities Case: The Role of Peace Agreements in International Conflict Resolution', (2008) 40 New York University Journal of International Law and Politics 107, at 145.

${ }^{5}$ See, e.g., Å. Kolås, 'Naga Militancy and Violent Politics in the Shadow of Ceasefire', (2011) 48 Journal of Peace Research 6; A. P. Harrisson and H. M. Kyed, 'Ceasefire State-Making and Justice Provision by Ethnic Armed Groups in Southeast Myanmar', (2019) 34 Journal of Social Issues in Southeast Asia 2; M. Sosnowski, 'Violence and Order: The February 2016 Cease-Fire and the Development of Rebel Governance Institutions in Southern Syria', (2018) 20 Civil Wars 3; K. Woods, 'Ceasefire Capitalism: Military-Private Partnerships, Resource Concessions and Military-State Building in the Burma-China Borderlands', (2011) 38 Journal of Peasant Studies 4.

${ }^{6}$ Harrisson and Kyed, ibid.

${ }^{7}$ M. Sosnowski, 'Ceasefires as violent statebuilding: local truce and reconciliation agreements in the Syrian civil war', (2020) 20 Conflict, Security and Development 2.

${ }^{8}$ Woods, supra note 5.

${ }^{9}$ M. Sosnowski, 'Negotiating statehood through ceasefires', (2020) 31 Small Wars and Insurgencies 5.

${ }^{10}$ V. P. Fortna, Peace Time: Cease-Fire Agreements and the Durability of Peace (2004), 45.

${ }^{11}$ Harrisson and Kyed, supra note 5; Sosnowski, supra note 5.

${ }^{12}$ Woods, supra note 5.

${ }^{13}$ Sosnowski, supra note 7.

${ }^{14}$ Kolås, supra note 5 ; Sosnowski, supra note 9.

${ }^{15}$ See, e.g., Public International Law \& Policy Group, The Ceasefire Drafter's Handbook (2013); D. Mancini-Griffoli and A. Picot, Humanitarian Negotiation: A Handbook for Securing Access, Assistance and Protections for Civilians in Armed Conflict (2004), 11-15; ICRC, Increasing Respect for International Humanitarian Law in Non-International Armed Conflicts (2008), 25; E. Heffes and M. D. Kotlik, 'Special Agreements Concluded by Armed Opposition Groups: Where is the Law', EJIL:Talk!, 27 February 2014, available at www.ejiltalk.org/special-agreements-concluded-by-armed-opposition-groups-where-is-the-law/. 
attests to the limitations of what these additional legal lenses can offer us in terms of better understanding, regulating or enforcing ceasefires. However, a third option that this article presents is to enlarge the emerging understanding of lex pacificatoria to go beyond applying primarily to peace agreements or comprehensive ceasefires, but also to partial ceasefire agreements in civil wars that are generally envisaged to be concluded well before the legal end of war. ${ }^{16}$ While international humanitarian law will nevertheless continue to apply and regulate ceasefire agreements concluded in armed conflicts, considering ceasefire agreements through an expanded lens of lex pacificatoria could enhance our thinking about where ceasefires fit in relation to other existing bodies of law, and in the long term, provide some 'programmatic standards' around negotiation, regulation, and enforcement. In this regard, I support the arguments of Christine Bell in relation to peace agreements, when she proposes that in the twilight space between war and peace, a clear legal regime that sets out hard legal obligations is not necessarily desirable. Rather, the programmatic standards of lex pacificatoria are meant to guide, and potentially provide normative expectations, around how the actions and dilemmas of ceasefire agreements can be handled and resolved alongside the requirements of international law. ${ }^{17}$

\section{From halting violence to complex political order}

Despite their long history (or perhaps because of it) there has been little agreement, and much confusion, around the nomenclature of the phenomenon of a ceasefire. Historically, the terms truce and armistice were used as synonyms, ${ }^{18}$ but in more recent history a raft of new names have been added to the lexicon that essentially describe the same phenomenon: 'a temporary cessation of violence that does not settle the larger conflict but is intended as a step in that direction'. ${ }^{19}$ These include cessation of hostilities, ${ }^{20}$ humanitarian pause, ${ }^{21}$ de-escalation, ${ }^{22}$ and (more creatively) Days of Tranquility, ${ }^{23}$ Safe Zones, Safe Corridors, ${ }^{24}$ and Windows of Silence. ${ }^{25}$ Some of these agreements are specifically designed to enable safe passage of non-combatants and humanitarian

\footnotetext{
${ }^{16}$ In their paper, 'Ceasefires in Intra-state Peace Processes', (2019), No. 252, CSS Analyses in Security Policy, G. Clayton et al. describe three types of ceasefires that come at different stages in a peace process: Cessation of Hostilities, preliminary and definitive. What I term 'partial ceasefires' in this article refers to both the Cessation of Hostilities and preliminary types.

${ }^{17} \mathrm{C}$. Bell, 'Of Jus Post Bellum and Lex Pacificatoria - What's in a Name?', in Stahn, Easterday and Iverson, supra note 1, 181 , at 192.

${ }^{18}$ Morriss, supra note 2.

${ }^{19}$ S. Smith, 'Ceasefire', in G. Burgess and H. Burgess (eds.), Beyond Intractability (2003), available at www.beyondintractability. org/essay/cease-fire.

${ }^{20}$ Joint Statement of the United States and the Russian Federation, as Co-Chairs of the ISSG, on Cessation of Hostilities in Syria, 22 February 2016, available at sy.usembassy.gov/joint-statement-united-states-russian-federation-co-chairs-issgcessation-hostilities-syria-february-22-2016/; Cessation of Hostilities Framework Agreement between the Government of the Republic of Indonesia and the Free Aceh Movement, 9 December 2002, available at peacemaker.un.org/sites/ peacemaker.un.org/files/ID_021209_Cessation\%20of\%20Hostilities\%20Framework\%20Gov\%20of\%20Indonesia\%20and\%20 Free\%20Aceh\%20Movement.pdf.

${ }^{21}$ A. Slemrod, 'UN calls for "humanitarian pause" in Yemen as conditions in capital deteriorate', The New Humanitarian, 4 December 2017, available at www.thenewhumanitarian.org/news/2017/12/04/un-calls-humanitarian-pause-yemenconditions-capital-deteriorate.

${ }^{22}$ Memorandum on the Creation of De-escalation areas in the Syrian Arab Republic, peaceagreements.org, 4 May 2017, available at www.peaceagreements.org/viewmasterdocument/2093.

${ }^{23}$ 'The UN calls for days of tranquility bears fruit; More than five million children have been vaccinated against Poliomyelitis in Sudan', Relief Web, 16 January 2005, available at reliefweb.int/report/sudan/un-call-days-tranquilitybears-fruit-more-five-million-children-have-been-vaccinated.

${ }^{24}$ G. Gilbert and A. M. Rusch, 'Creating Safe Zones and Safe Corridors in Conflict Situations: Providing Protection at Home or Preventing the Search for Asylum?', (2017) Kaldor Centre for International Refugee Law, Policy Brief 5.

${ }^{25}$ OSCE mirror patrols: Windows of hope in Eastern Ukraine, 12 April 2017, available at www.osce.org/stories/osce-mirrorpatrols-windows-of-hope-eastern-ukraine.
} 
supplies while others are related to immediate health and access concerns, such as immunization campaigns and food delivery. Despite the convoluted terminology, so far all of the above have been seen predominantly in relation to how they affect violence being variously defined by their ability to halt fighting, ${ }^{26}$ as 'an end to or break in the fighting, ${ }^{27}$ or as 'a suspension of acts of violence by military and paramilitary forces' ${ }^{28}$ There is no agreement as to whether the different terms have slightly different meanings or whether they can be used interchangeably to describe the same or similar phenomenon. Consequently, the overwhelming focus on ceasefires, in practice and in scholarship and regardless of what they are called, remains on them as a way to stop or reduce the use of violence for periods of time or as a preliminary step that builds trust between belligerents and in the process offers space to negotiate a comprehensive ceasefire and/or a peace agreement.

Legal scholars have also encountered the 'semantic tangle' of ceasefires, ${ }^{29}$ lamenting that this 'reveals the dilemma in which the international law of war finds itself in this area with no general understanding .... as to the meaning of any of the numerous terms used in connection with the cessation of hostilities'. ${ }^{30}$ Some authors have laid the blame at the door of the UN where words have been used in a disjointed, ad hoc fashion 'without regard to their prior usage and, worse still, inconsistently. ${ }^{31}$ In practical terms, however, as far as the UN is concerned, a Chapter VII-based ceasefire aimed at ensuring international peace and security or a decision of the Security Council is a binding order establishing a legal duty to comply despite no guarantee of compliance. ${ }^{32}$ Peace agreements, like ceasefire agreements, often contemplate some type of international involvement to act in a monitoring capacity or to secure implementation (e.g., from complete international administration in Bosnia or Kosovo to the more ad hoc involvement of specific personalities for one-off tasks, such as decommissioning in Northern Ireland). ${ }^{33}$ However, this involvement means that substantively, these types of agreements cannot be clearly divided into legally binding and non-binding arrangements of either domestic or international law. ${ }^{34}$ Likewise, international humanitarian law also has relatively few provisions relating specifically to when ceasefire agreements should be negotiated, what they need to contain or how their terms need to be applied. ${ }^{35}$ It does, however, stipulate that a 'truce' does not entail the suspension of the application of international humanitarian law or put an end to the legal state of war and its associated legal consequences, but gives no more specific guidance on what acts are permitted or forbidden during a ceasefire beyond those already envisaged by international humanitarian law. ${ }^{36}$

\footnotetext{
${ }^{26}$ L. Chounet-Cambas, 'Ceasefires', (2016) GSDRC Professional Development Reading Pack 41, at 1: 'agreements, facilitated by a third party, that define the rules and modalities for conflict parties to stop fighting'.

${ }^{27}$ Fortna, supra note 10, at 45.

${ }^{28}$ S. D. Bailey, 'Cease-Fire, Truces and Armistices in the Practice of the UN Security Council', (1977) 71 American Journal of International Law 3, at 469.

${ }^{29}$ Lang, supra note 4, at 147.

${ }^{30}$ H. S. Levie, 'Recueils de La Societe International de Droit Penal Militaire et de Droit de La Guerre, Sixieme Congres International. La Haye, 22-25 Mai 1973. Volume 1: Le Cessez-Le Feu’, (1976) 70 American Journal of International Law 2.

${ }^{31}$ Ibid.

${ }^{32}$ Henderson and Lubell, supra note 2, at 813.

${ }^{33}$ C. Bell, 'Peace Settlements and International Law - from Lex Pacificatoria to Jus Post Bellum', in N. White and C. Henderson (eds.), Research Handbook on International Conflict and Security Law (2013), at 499.

${ }^{34}$ Bell, supra note 1; C. Bell, On the Law of Peace: Peace Agreements and the Lex Pacificatoria (2008); C. Wittke, Law in the Twilight: International Courts and Tribunals, the Security Council and the Internationalisation of Peace Agreements Between State and Non-State Parties (2018), 48, 62.

${ }^{35}$ Art. 15 of Geneva Convention I does contemplate that parties to an international armed conflict might agree to an armistice or suspension of fire in order to establish arrangements aimed at permitting the removal, exchange, or transport of the wounded left on the battlefield; the removal or exchange of the wounded and sick from a besieged or encircled area; or the passage of medical and religious personnel and equipment en route to a besieged or encircled area.

${ }^{36}$ Arts. 32-34 of the Hague Regulations 1907 relating to truces and armistices; Art. 37/1(a) of Additional Protocol 1; Rule 58 of Customary International Humanitarian Law.
} 
This lacuna and linguistic malaise are far from ideal. In practice, the signatories to a ceasefire seem to get to decide on the public name that it goes by - a marketing ploy for what are in fact important agreements between belligerents that have real ramifications for civilians and combatants. ${ }^{37}$ Likewise, from a matter-of-fact perspective, even partial ceasefire agreements are significant documents in the arena of war and what they contain has consequences on the ground - if they did not, why would belligerents invest time and resources into negotiating their terms? Moreover, if these ramifications are not just related to violence, but are often self-serving, strategic and highly political, ${ }^{38}$ it seems logical to suggest that there should be some sort of more encompassing legal regime by which to assess, and possibly regulate, the legality of the actions of parties during a ceasefire agreement.

The potential for ceasefires to allow parties to an armed conflict time and space to re-equip and resupply troops or move them to more strategically important areas is a familiar refrain on the battlefield and in negotiation settings. ${ }^{39}$ It is also generally accepted that conflict parties are in the business of maximizing their own benefits, and that in order to do this they may use strategies related to the timing, ${ }^{40}$ legitimacy, ${ }^{41}$ structure, and terms of ceasefire negotiations to their own advantage. ${ }^{42}$ However, new research in the fields of anthropology, security, and development studies has suggested that a halt in war (however long it may be) is not necessarily 'peace', but a more amorphous environment that is in some ways distinct from the previous violence, but in others, inherently linked to it. ${ }^{43}$ These critical scholars of law, ${ }^{44}$ international studies, ${ }^{45}$ development, ${ }^{46}$ political geography, ${ }^{47}$ anthropology, ${ }^{48}$ and security, ${ }^{49}$ have taken up the refrain of seeing the transition between war and peace not so much as a transition, but rather as 'a continuous process of negotiation and shifting alliances between a wide range of actors that wield allegiances and resources'. ${ }^{50}$ Terms such as 'mediated state', ${ }^{11}$ 'hybrid political order', ${ }^{52}$

\footnotetext{
${ }^{37}$ M. Salehi, 'Designing transitional justice: Problems of planning political \& institutional change in volatile political contexts', (2020) POMEPS Studies 37: Challenges to the Middle East North Africa Inclusionary State; M. Sosnowski, 'Reconciliation agreements as strangle contracts: ramifications for property and citizenship rights in the Syrian civil war', Peacebuilding, 22 July 2019, available at doi.org/10.1080/21647259.2019.1646693.

${ }^{38}$ S. J. Stedman, D. Rothchild and E. M. Cousens, Ending Civil Wars: The Implementation of Peace Agreements (2002).

${ }^{39}$ L. Chounet-Cambas, 'Negotiating Ceasefires: Dilemmas \& Options for Mediators', (2011) Mediation Practice Series, The Centre for Humanitarian Dialogue, at 7-8, 20; A. C. Crocker, F.O. Hampson and P. R. Aall, Taming Intractable Conflicts: Mediation in the Hardest Cases (2004), 158; S. S. Gartner and M. M. Melin, 'Assessing Outcomes: Conflict Management and the Durability of Peace', (2009) SAGE Handbook of Conflict Resolution, at 566; M. D. Toft, 'Ending Civil Wars: A Case for Rebel Victory?', (2010) 34 International Security 4, at 15. For an example of how this occurred in the Syrian civil war see, e.g., J. Di Giovanni, The Morning They Came For Us: Dispatches from Syria (2016), 165.

${ }^{40}$ S. Mahieu, 'When Should Mediators Interrupt a Civil War? The Best Timing for a Ceasefire', (2007) 12 International Negotiation 2.

${ }^{41} \mathrm{~K}$. Höglund, 'Tactics in Negotiations between States and Extremists: The Role of Cease-Fires and Counterterrorist Measures', in I. W. Zartman and G. O. Faure (eds.), Engaging Extremists: Trade-Offs, Timing, and Diplomacy (2011).

${ }^{42}$ See, e.g., O. Richmond, "Devious Objectives and the Disputants" View of International Mediation: A Theoretical Framework', (1998) 35 Journal of Peace Research 6; Stedman, Rothchild and Cousens, supra note 38, at 12.

${ }^{43}$ C. Steenkamp, 'In the Shadows of War and Peace: Making Sense of Violence after Peace Accords', (2011) 11 Conflict, Security and Development 3.

${ }^{44}$ Bell, supra note 17; C. Wittke, 'The Minsk Agreements-More than “Scraps of Paper"?', (2019) East European Politics 9165.

${ }^{45} \mathrm{P}$. Meehan, 'The Militia Fix: Ordering space at the margins of the Myanmar state', paper presented at the EWIS conference, 6-7 June 2018, Groningen, The Netherlands.

${ }^{46}$ C. Cramer, Civil War Is Not a Stupid Thing: Accounting for Violence in Developing Countries (2006).

${ }^{47}$ B. Korf, M. Engeler and T. Hagmann, 'The Geography of Warscape', (2010) 31 Third World Quarterly 3.

${ }^{48}$ S. C. Lubkemann, Culture in Chaos: An Anthropology of the Social Condition in War (2008).

${ }^{49}$ Steenkamp, supra note 43.

${ }^{50} \mathrm{~B}$. Klem, In the Wake of War: The Political Geography of Transition in Eastern Sri Lanka (2012), PhD dissertation, University of Zurich, at 34 .

${ }^{51}$ K. Menkhaus, 'Governance without Government in Somalia', (2006) 31 International Security 3.

${ }^{52}$ V. Boege et al., 'On Hybrid Political Orders and Emerging States: State Formation in the Context of "Fragility”', (2008) Berghof Handbook Dialogue No. 8, Berghof Research Center.
} 
and 'political marketplace' ${ }^{53}$ have been coined to emphasize the point that peace is not simply an end state. Rather, regardless of whether a state is classified as being in a legal state of war or at peace, actors exist in a patrimonial marketplace in competition for allegiances and support. ${ }^{54}$

Consequently, rather than a ceasefire being seen as the first step on the road towards peace, ${ }^{55}$ new thinking about the dynamic and evolving nature of violence and peace, power, and authority can help us broaden our thinking about the type of legal documents ceasefire agreements are. If authority in and over different relationships, institutions, and resources is not fixed or able to be imposed, but rather in a continuous process of negotiation and change as many authors suggest, then ceasefire agreements are not only intervening in struggles relating to the use of violence, but potentially many more contestations for important assets and associations. In this way, looking at ceasefire agreements in a legally narrow sense - as a brief nap in the broader arena of warfare - risks blinding us to their important legal nature and the myriad consequences of these agreements.

Roger Mac Ginty states that ceasefire agreements can potentially be used as 'something more than a negotiating-enabling stopgap in violent conflicts' ${ }^{56}$ However, thus far, ceasefire agreements have not been considered to be important legal documents, particularly when compared to peace agreements. What they actually are and what they do continues to be overwhelmingly considered in relation to more traditional, and arguably outdated ways of understanding war and peace. As such, looking beyond their ability to halt violence, it is more beneficial to define ceasefires as the codification of a certain military and political state of affairs during wartime. This means that the text of a ceasefire, i.e., its codification, has the ability to affect power relationships between different actors, and these have subsequent ramifications for military and political affairs on-theground. So far, a teleological way of thinking about how the law applies to times of war and peace and the role ceasefire agreements play in this transition, has meant that scholars and practitioners have remained blinkered as to the complex legal nature and ramifications of ceasefire agreements. Directly below, I present two legal lenses that have been used to think about ceasefire agreements more broadly - as contractual documents, and as special agreements under Common Article 3 of the Geneva Conventions. However, as will be shown, both these legal paradigms have limitations. This is mainly due to the fact that they are too rigid and not able to be enforced in practice. This brings me to the main suggestion of this article - that we broaden the emerging realm of lex pacificatoria to also apply to partial ceasefire agreements agreed to before a final peace deal or comprehensive ceasefire in civil wars. Doing so brings a rule-based system to the governance of ceasefires, but at the same time continues to offer the flexibility ceasefire negotiators and parties to an armed conflict need in order to navigate the ephemeral space between war and peace.

\section{Ceasefires as contractual documents}

The bibliographies of papers written about how to negotiate ceasefire agreements contain a range of texts relating to the broader fields of negotiation theory, the practicalities of negotiating in the legal and business worlds, the psychology of negotiation, negotiating across cultures, genders and in everyday life. ${ }^{57}$ A common inclusion is Roger Fisher and William Ury's popular book Getting to Yes. Therein, Fisher and Ury state that while negotiating is not all about winning on the merits, 'losing is not the answer' either, and that negotiations, whether they be in a hostage-situation, for

\footnotetext{
${ }^{53}$ A. De Waal, 'Mission without End? Peacekeeping in the African Political Marketplace', (2009) 85 International Affairs 1. ${ }^{54}$ Ibid.

${ }^{55}$ J. P. Lederach, 'Cultivating Peace: A Practitioner's View of Deadly Conflict and Negotiation', in J. Darby and R. Mac Ginty (eds.), Contemporary Peacemaking: Conflict, Peace Processes and Post-war Reconstruction, (2008), at 36-44.

${ }^{56} \mathrm{R}$. Mac Ginty, No War, No Peace: The Rejuvenation of Stalled Peace Processes and Peace Accords (2008), 111.

${ }^{57}$ See, e.g., Chounet-Cambas, supra note 39; Public International Law \& Policy Group, supra note 15; Mancini-Griffoli and Picot, supra note 15 .
} 
the sale of a house or a pay-rise, should produce 'substantive outcomes' ${ }^{58}$ The message that underpins a lot of this practical scholarship is that negotiating contractual understandings in everyday life or in the business world is not fundamentally different in form to negotiating a ceasefire agreement. While the substance may differ from case to case, in interpersonal negotiations over just about anything, a logic of reciprocity has emerged which assumes that parties have to give something in exchange for reaching their overall objective. ${ }^{59}$

The Ceasefire Drafter's Handbook - a practical guide to negotiating ceasefire agreements in the Getting to Yes mould - posits that the legality of a ceasefire depends on four points. These are: whether the ceasefire agreement constitutes a treaty (most likely in an interstate conflict); whether it is signed as part of a formal written document; whether it is precisely drafted with clear rights and responsibilities for each of the parties involved; and finally, whether there is a third-party that helps negotiate the terms and has the power to interpret and/or enforce them. ${ }^{60}$ Additionally, 'ceasefire parties should not miss the opportunity to create a strong sense of legal obligation through a structured, precise document that includes the participation of third parties'. ${ }^{61}$ But, how does this square with the assertion of international law that ceasefires are not legally binding documents, or that the rules of jus in bello continue to apply regardless?

One possible explanation may be that while ceasefire agreements are not a contract in the business sense, or technically legally binding in and of themselves, a ceasefire agreement certainly has most if not all of the elements of a common-sense way of understanding contractual negotiation and agreement. These include the fact that ceasefires are generally in writing, ${ }^{62}$ include a number of carefully worded terms and clauses, are frequently negotiated with the help of an international third party, and are signed by the parties to the agreement. ${ }^{63}$ When viewed objectively, a reasonable assumption from a lay observer is therefore that ceasefire agreements constitute a type of contract. Disregarding issues of jurisdiction and whether or not they are able to be enforced, at the very least their formal outward characteristics give ceasefire documents an air of contractuality.

Additionally, in civil wars such as Syria, Yemen or Iraq, ceasefire negotiators are increasingly coming up against the assumption of belligerents that a quid pro quo arrangement is necessary in order to secure a ceasefire agreement. For example, during the civil war, the Syrian government agreed to a ceasefire with the non-state armed group operating in the town of Zabadani in exchange for opposition fighters ceasing attacks against military installations and convoys and dismantling the checkpoints they had established around the city. ${ }^{64}$ Likewise in Yemen, Saudi Arabia agreed to a ceasefire in Hodeidah in exchange for Houthi forces redeploying from the city, as well as from the ports of Salif and Ras Isa. ${ }^{65}$ Evidently, the element of reciprocity, unnecessary in conventional ways of thinking about ceasefire agreements as a tool primarily to alleviate violence, is a key part of ceasefire negotiations in contemporary civil wars. This has created a situation where belligerents expect a return for their supposedly charitable gesture of ceasing fire.

\footnotetext{
${ }^{58} \mathrm{R}$. Fisher and W. Ury, Getting to Yes: Negotiating an agreement without giving in (1999), 154.

${ }^{59} \mathrm{C}$. Bruderlein, 'Challenges \& dilemmas in frontline negotiations: Interview with Claude Bruderlein', Humanitarian Law and Policy, 4 January 2018, available at blogs.icrc.org/law-and-policy/2018/01/04/challenges-dilemmas-in-frontlinenegotiations-interview-with-claude-bruderlein/.

${ }^{60}$ Public International Law \& Policy Group, supra note 15, at 6.

${ }^{61}$ Ibid., at 8.

${ }^{62} \mathrm{Or}$ at least, made publicly available by some sort of unilateral declaration, such as a video recording or public statement. This has been the case in many conflicts including Myanmar, Sudan, and Ethiopia.

${ }^{63}$ Bell, supra note 17 , at 183 .

${ }^{64}$ S. Araabi and L. Hilal, 'Reconciliation, Reward and Revenge: Analyzing Syrian De-Escalation Dynamics through Local Ceasefire Negotiations', (2016) Berghof Foundation, at 22.

${ }^{65}$ Agreement on the City of Hodeidah and Ports of Hodeidah, Salif and Ras Isa, available at osesgy.unmissions.org/sites/ default/files/hodeidah_agreement_0.pdf.
} 
This dynamic of reciprocity, taken from business-style mediation and contractual negotiations, and applied to ceasefire agreements, implies that the 'favour' of ceasing fire will only be granted in return for something else, such as troop withdrawal or humanitarian access. Unfortunately, one negative consequence of the 'commercialization' of the ceasefire negotiation process is that it obscures a range of other salient dynamics and assets that conflict parties may be fighting over or interested in securing. Likewise, even if a ceasefire agreement is considered a contractual document, it remains unrealistic to expect enforceability to always come through the physical intervention of a third party. ${ }^{66}$ Practically speaking, this makes the benefits of using this as an additional legal lens to augment the efficacy of international humanitarian law relatively limited. While signing a ceasefire agreement that is also considered to be a legal contract may help in legitimizing certain conflict actors, it arguably does little to assist with compliance or enforceability, particularly regarding contested areas beyond violence. $^{67}$

\section{Ceasefires as special agreements under Common Article 3}

Special agreements are a tool used by ceasefire negotiators and belligerents to underscore an express commitment to specific elements of international humanitarian law or to reinforce pledges to abide by additional legal paradigms, such as human rights law. For example, in a 2002 ceasefire agreement between the government of Angola and rebel group UNITA, the parties agreed to guarantee the protection of persons and their property, and not to conduct forced movements of the civilian population, commit acts of violence against the civilian population, or destroy property. ${ }^{68}$ Likewise, the 2002 ceasefire agreement between the Sri Lankan government and the Liberation Tigers of Tamil Eelam included a commitment to abstain from torture and intimidation. ${ }^{69}$ While humanitarian organizations such as the International Committee of the Red Cross are not always directly involved in ceasefire negotiations, the terms of the agreements act as a reminder to the parties of their obligations under international humanitarian law. Ideally, this encourages compliance with the law and/or helps to negotiate humanitarian access. Examples include representations made as part of the 1999 ceasefire agreement in the Democratic Republic of the Congo, and on the basis of the 2002 agreement on a cessation of hostilities between the government of Indonesia and the GAM. ${ }^{70}$ This means that while special agreements do not themselves guarantee increased respect for international humanitarian law, they nevertheless provide a basis on which legal representations can be made, and on which accountability can be required. ${ }^{71}$ They may also form grounds for follow-up action to address violations of those commitments, providing additional leverage for representations. ${ }^{72}$

\footnotetext{
${ }^{66}$ B. F. Walter, 'The Critical Barrier to Civil War Settlement', (1997) 51 International Organization 3.

${ }^{67}$ Conciliation Resources, Legitimacy and Peace Processes: From Coercion to Consent (2014).

${ }^{68}$ Text of the Luena Memorandum of Understanding (Addendum to the Lusaka Protocol for the Cessation of Hostilities and the Resolution of the Outstanding Military Issues under the Lusaka Protocol), 4 April 2002, available at www.peaceagreements.org/search?SearchForm $\% 5$ Bregion $\% 5 \mathrm{D}=\&$ SearchForm $\% 5$ Bcountry_entity\%5D=9\&SearchForm $\% 5 \mathrm{Bname} \% 5 \mathrm{D}=\&$ SearchForm $\% 5$ Bcategory_mode $\% 5 \mathrm{D}=$ any\&SearchForm $\% 5$ Bagreement_text $\% 5 \mathrm{D}=\& \mathrm{~s}=$ Search $+\mathrm{Database}$.

${ }^{69}$ Text of the Agreement on a Ceasefire between the Government of the Democratic Socialist Republic of Sri Lanka and the Liberation Tigers of Tamil Eelam, 22 February 2002, available at www.peaceagreements.org/search?SearchForm\%5Bregion\% $5 \mathrm{D}=\&$ SearchForm $\% 5$ Bcountry_entity $\% 5 \mathrm{D}=129 \&$ SearchForm $\% 5$ Bname $\% 5 \mathrm{D}=\&$ SearchForm $\% 5$ Bcategory_mode $\% 5 \mathrm{D}=$ any $\&$ SearchForm $\% 5$ Bagreement_text $\% 5 \mathrm{D}=\& \mathrm{~s}=$ Search+Database.

${ }^{70}$ ICRC, Increasing Respect for International Humanitarian Law in Non-International Armed Conflicts (2008), 25.

${ }^{71}$ Ibid., at 16 .

${ }^{72}$ Ibid., at 27 .
} 
The International Committee of the Red Cross has stated that:

The fact that an identifiable leader for each party has signed a special agreement, thereby taking on responsibility to ensure that the agreement is adhered to, will not only provide a contact person and reference point for future representations, but also send a clear signal to his forces. Furthermore, given that a special agreement is very likely to be made public, a wide range of actors in the international community will be aware of it and may be able to help in holding the parties to their commitments.

Non-state armed groups are obliged to comply with a minimum set of international humanitarian law rules (e.g., those contained in Common Article 3). However, non-state groups exercising control of territory potentially have added legal obligations under Additional Protocol II and human rights law. ${ }^{73}$ Through special agreements, parties to a conflict, including non-state armed groups, may bring into force all or part of the four Geneva Conventions. Therefore, theoretically, additional legal obligations could be brought into being through the enactment of special agreements. ${ }^{74}$ However, as international humanitarian law continues to apply during a ceasefire, there are no legal consequences for a party that does not include commitments that expressly constitute (or augment) a special agreement in a ceasefire agreement. That is to say that a party to a conflict will be bound by minimum standards of international humanitarian law regardless of whether it agrees to make a special agreement to commit to additional rules of international law or not. The above examples of ceasefire agreements all contain terms that commit their signatories to international humanitarian law without any reference to the fact that they are technically special agreements. Therefore, it seems nonsensical to imply that special agreements need to be expressly negotiated and agreed upon unless they add to the legal rules which apply in any case.

We could therefore consider all ceasefire agreements as incorporating the special agreement tool from the get-go. This could serve as a way to encourage compliance with international humanitarian law or potentially other legal regimes such as human rights law. However, states have been particularly hesitant to reframe ceasefire agreements as special agreements. One explanation for this may be that they consider that entering into a ceasefire with a non-state armed group that is explicitly labelled as a special agreement will grant the group additional legitimacy. While Common Article 3 makes it clear that concluding a special agreement in no way affects the legal status of the parties to the conflict, the hesitancy of states affirms the importance of performative acts having practical potential, particularly in the contested environment of war. ${ }^{75}$ An additional obstacle to the conclusion of a special agreement may also be the unwillingness of the parties to commit themselves to a broader range of legal obligations than would otherwise be required. On the one hand this is understandable, but on the other, it therefore means that this legal lens offers us little in the way of expanding or enhancing our current understanding of the legality of ceasefire agreements.

\section{Broadening the application of lex pacificatoria}

Over the past two decades, Christine Bell has pioneered research into a new legal field she calls lex pacificatoria. ${ }^{76}$ This emergent lex offers an attempt to deal with the messy politico-legal space between war and peace that peace agreements occupy. As such, lex pacificatoria is envisaged

\footnotetext{
${ }^{73}$ K. Fortin, 'The Application of Human Rights Law to Everyday Civilian Life Under Rebel Control', (2016) 63(2) Netherlands International Law Review 161.

${ }^{74}$ Heffes and Kotlik, supra note 15.

${ }^{75}$ J. Martínez and B. Eng, 'Stifling Stateness: The Assad Regime's Campaign against Rebel Governance', (2018) 49 Security Dialogue 4.

${ }^{76}$ See, e.g., Bell, supra note 1; Bell, supra note 33; Bell, supra note 17; C. Bell and J. Pospisil, 'Navigating Inclusion in Transitions from Conflict: The Formalised Political Unsettlement', (2017) 29 Journal of International Development 5.
} 
to exist in the transitional space between jus in bello and jus post bellum. It is always emergent and never wholly formed mainly because the temporal element of deciding when war has ended is a tricky, contested, and often political business. ${ }^{77}$ As a result of this, Bell argues that agreements reached in peace processes differ from other types of legal agreements because they share a 'transitional and temporal character', and can thus only be understood in terms of 'what has gone before and what will come after' ${ }^{78}$ This gels with the work of other scholars working in the field of war to peace transitions who also suggest that peace is a hard thing to pin down, and that the end of war is in reality a contested and nebulous environment that is always relational to the violence that has preceded it. ${ }^{79}$ Further, Bell suggests that peace agreements need to be understood in light of a combination of domestic and international components, and in recognition of the fact that the enforcement of a peace agreement depends on political processes. ${ }^{80}$ The overriding logic of lex pacificatoria is, therefore, that the purpose of international law as it relates to peace settlements is not to regulate negotiation outcomes, but rather to set out broad normative parameters or 'programmatic standards' that support the idea that negotiated outcomes should be both capable of implementation and accord with some sense of justice. Lex pacificatoria attempts to achieve this while simultaneously leaving room for the contestation and negotiation over what concepts such as 'accountability', 'justice', and even 'peace' mean and may require in different contexts. ${ }^{81}$

This stands in contrast to scholarship in the area of jus post bellum, which is firmly based on the 'harder' laws of war and uses them as a way to regulate the post-conflict domain. It proposes codifying and extending the existing laws of war in order to build up a tripartite set of rules that complements the already existent jus ad bellum and jus in bello. As such, it is envisaged that each body of law will focus on a specific temporal period of war - the beginning, middle or end - with jus post bellum being needed to regulate post-conflict tasks. ${ }^{82}$ However, it remains legally and politically uncertain when the 'end of a conflict' exactly is. It is also unclear whether the end of war refers to a halt in violence, often achieved by a partial ceasefire agreement, or whether it relates to a more formalized close of hostilities, usually achieved via a peace agreement or comprehensive ceasefire, military victory or surrender. ${ }^{83}$ The ambiguity over when jus post bello kicks in also points to a larger malaise recognized in both legal and social science scholarship. While declarations of war ${ }^{84}$ or peace agreements may technically mark the launch or closure of an armed conflict, deciding when war and peace begins and ends is a lot more tricky (and often political) in practice. This means that transitional periods where the diverse mechanics of peacebuilding occur, such as the negotiation of ceasefire agreements, are much more fluid, and therefore, harder to grasp conceptually and regulate legally.

For the purpose of this article, it is not necessary to fully agree with any side of the temporal debate between jus post bellum and lex pacificatoria. However, what is relevant to assert anew is that while both bodies of law have primarily been thought of in relation to what are generally considered to be definitive peace agreements, partial ceasefire agreements are an intrinsic part of peace processes, but have not yet been adequately examined by either of these legal canons. Therefore, whether they are considered unilateral, temporary, partial or part of a definitive peace agreement, ceasefire agreements also fall under the rubric of both legal regimes. What is appealing about lex pacificatoria in terms of its applicability to ceasefires signed before a definitive peace

\footnotetext{
${ }^{77}$ Bell, supra note 17.

${ }^{78}$ C. Bell, Peace Agreements and Human Rights (2000), 305.

${ }^{79}$ See, e.g., B. Klem, 'The Problem of Peace and the Meaning of "Post-War", (2018) 18 Conflict, Security \& Development 3; Steenkamp, supra note 43.

${ }^{80}$ Bell, supra note 78 , at 305 .

${ }^{81}$ Bell, supra note 17 , at 503.

${ }^{82}$ Stahn, Easterday and Iverson, supra note 1.

${ }^{83}$ S. Sivakumaran, The Law of Non-International Armed Conflict (2012), at 252-4.

${ }^{84} \mathrm{With}$ the rise of non-international armed conflicts in the contemporary era, these are now virtually non-existent. Instead, using a codified legal process, the legal state of war is generally classified and announced by the ICRC.
} 
agreement, is that instead of offering strict binary divisions between war and peace, the more amorphous environment created by what are commonly referred to as partial, lite or preliminary ceasefires is potentially better 'governed' by a lex that is flexible and lends itself to negotiation and compromise rather than the application of fully formed legal norms. In this vein, the categorization of ceasefire agreement terms as being either legally binding or non-binding may be too simplistic to capture the nuance and flexibility required during ceasefire negotiations. Perhaps a better approach is to locate ceasefires on a legal continuum from low to high legalization. ${ }^{85}$ Many scholars and practitioners have already noted that ceasefire agreements are certainly more than just 'scraps of paper'. ${ }^{86}$ Likewise, and as mentioned above, as the growing body of work on ceasefires being undertaken in anthropology, development, and security studies shows, ceasefire agreements have a range of consequences on the ground, regardless of their enforceability, supposed success or legality. Therefore, applying a legal regime such as lex pacificatoria to ceasefires signed before a definitive ceasefire or peace agreement that is able to cope with this diversity is potentially helpful in enhancing our conceptual understanding of what happens on the ground, and could potentially be quasi-regulated, in the space between war and peace.

For example, the Minsk Agreements, a series of ceasefire agreements signed between Russia, Ukraine, and separatist groups operating in the Donetsk and Luhansk region of Ukraine that are supported by Russia, have not brought peace, but continue to shape processes of dialogue and negotiation over the effective and legitimate exercise of political power in the eastern regions of Ukraine. ${ }^{87}$ These include in relation to governance, ${ }^{88}$ legal identity, ${ }^{89}$ and security. ${ }^{90}$ In 2017, Ukraine also submitted a suit against Russia to the International Court of Justice in a (creative) attempt to hold Russia accountable for breaching the terms of the Minsk Agreements. ${ }^{91}$ In their arguments, both parties directly and indirectly addressed disagreements within the legal and scholarly community about the legal status of ceasefire agreements. ${ }^{92}$ In doing so, they underscored the reality that ceasefires sit at a juncture in armed conflict where the division between the fields of politics and law is increasingly blurred. The submissions also point to the fact that both conflict parties were cautious about how ceasefire agreements can be used to contest legitimacy and authority, and can potentially create forms of responsibility for signatories. ${ }^{93}$

Cindy Wittke has suggested that attempts to characterize and categorize ceasefire agreements in politico-legal contexts will ultimately reveal a 'lack of fit', where:

[L]ack of fit indicates metaphorically that peace and ceasefire agreements are usually negotiated in the grey zones between ongoing violent conflicts, the cessation of immediate violence, and the initiation of a sustainable peace process. Moreover, lack of fit could also

\footnotetext{
${ }^{85}$ Wittke, supra note 44 , at 277.

${ }^{86}$ V. P. Fortna, 'Scraps of Paper? Agreements and the Durability of Peace', (2003) 57(2) International Organization 337.

${ }^{87}$ Wittke, supra note 44 , at 285.

${ }^{88}$ O. Lennon and G. Adams, 'All Is Quiet on the Russian Front: Ceasefires and the Pursuit of Legitimacy by Self-Proclaimed "Republics" in Ukraine', (2019) Eurasian Geography and Economics.

${ }^{89} \mathrm{~K}$. Fortin, 'To be or not to be?: legal identity in crisis in non-international armed conflicts', Human Rights Quarterly (forthcoming November 2020).

${ }^{90}$ A. K. Talentino, 'Intervention as Nation-Building: Illusion or Possibility?', (2002) 33 Security Dialogue 1.

${ }^{91}$ Application of the International Convention for the Suppression of the Financing of Terrorism and of the International Convention on the Elimination of All Forms of Racial Discrimination (Ukraine v. Russia), Application Instituting Proceedings, 16 January 2017, ICJ.

${ }^{92}$ See, e.g., Application of the International Convention for the Suppression of the Financing of Terrorism and of the International Convention on the Elimination of All Forms of Racial Discrimination (Ukraine v. Russia) Verbatim Record, CR 2017/2 p. 15 para. 20, 18, paras. 9-10; Verbatim Record, CR 2017/3, 17-18, paras. 15-16.

${ }^{93}$ Wittke, supra note 44.
} 
point to the question of whether law, be it domestic and/or international, is at all "fit" to deal with the challenges of peace agreements. ${ }^{94}$

These are, of course, real concerns. In the liminal, grey space between war and peace that peace and ceasefire agreements occupy, it is tricky, perhaps even undesirable, to give ceasefire agreements additional legal meaning. This also points to the fact that instead of visualizing peace as an end point or focusing on explaining a particular outcome, understanding the dynamics of a process, how it evolves and why it does so is essential. ${ }^{95}$

\section{Conclusion: Ceasefires and international law}

International law imposes obligations on states, non-state parties and individuals which cannot be bargained away. However, in reality, power enables parties to obfuscate these obligations or at the least, pick and choose when and where they decide to fulfil them. ${ }^{96}$ The ability to invoke deference to national legal obligations or defer to the orders of a superior were deemed officially defunct at the Nuremburg Trials of the 1940s. However, even in the 1930s, ICRC delegate, Marcel Junod, noted that, in the Spanish Civil War, and during the Italian invasion of Abyssinia, it was never enough to just rely on the persuasive power of international law. ${ }^{97}$ Other factors need to be drawn upon from which to make a convincing legal argument. ${ }^{98}$

But, at the same time, Louis Henkin has contended that, '[i]t is probably the case that almost all nations observe almost all principles of international law and almost all of their obligations almost all of the time'. ${ }^{99}$ This points to the fact that the international community is ordered around certain social, political and legal norms, ${ }^{100}$ and that this structure has the ability to mould and shape the actions of actors even in the absence of vertical enforcement mechanisms. ${ }^{101}$ Law comes into effect via rules, practices, and institutions that socially construct the law through the perception of the actors it applies to. ${ }^{102}$ The perception of legality makes it harder for actors to denounce unilaterally. In suggesting that we broaden our understanding of ceasefire agreements to incorporate additional legal lenses - such as contractual documents, as special agreements or ideally as part of an emerging lex pacificatoria - my hope is to add to the social construction of the legality of ceasefire agreements in order to make them better able to form part of the already common set of rules, principles and practices that govern the international legal system. This is all the more important in contemporary civil war environments because compliance depends more and more on legal status and (real or perceived) censure than physical enforcement mechanisms.

There is an old Arab proverb that goes, '[k]now each other as if you were brothers; negotiate deals as if you were strangers to each other'. Fixating only on how ceasefire agreements affect violence does not help us analyse, negotiate or regulate them with fresh eyes - 'as if they were strangers'. To this end, this article has used relatively new thinking from the social sciences about the diverse ramifications of ceasefires to point out the necessity of broadening existing legal

\footnotetext{
${ }^{94}$ Wittke, supra note 44 , at 276.

${ }^{95}$ M. Åkebo, The Politics of Ceasefires: On Ceasefire Agreements and Peace Processes in Aceh and Sri Lanka (2013), PhD dissertation, Umeå University, at 33.

${ }^{96}$ Mancini-Griffoli and Picot, supra note 15.

${ }^{97}$ J. Marcel, Le troisième combattant (1989).

${ }^{98}$ J. Cropp, The Humanitarian Fix: An Ethnography of Civilian Protection in Contemporary Wars (2019), PhD dissertation, University of Melbourne.

${ }^{99}$ L. Henkin, How Nations Behave (1979), 97.

${ }^{100}$ A. Orford, 'Constituting Order', in J. Crawford and M. Koskenniemi (eds.), The Cambridge Companion to International Law (2012), 271.

${ }^{101} \mathrm{D}$. Zartner, 'The Culture of Law: Understanding the Influence of Legal Tradition on Transitional Justice in Post-Conflict Societies', (2012) 22 Indiana International and Comparative Law Review 2, at 297.

${ }^{102}$ Lang, supra note 4 , at 149.
} 
understandings of ceasefire agreements. In considering three additional legal lenses, this article also canvasses some of the implications for understanding ceasefire agreements as documents with additional legal meaning rather than as being governed solely under the purview of international humanitarian law as military instruments used to suspend hostilities. ${ }^{103}$ It finds that considering ceasefire agreements as contractual documents or as special agreements under Common Article 3 is too rigid to enable them to be meaningfully implemented in the contested and twilight space that ceasefires occupy during wartime. Instead, expanding lex pacificatoria to cover partial ceasefire agreements offers an opportunity not only to regulate the violent ramifications of ceasefires, but myriad other spaces such as governance, rights, economics and security. In providing flexible programmatic standards rather than legal proscriptions, at best, it offers an enhanced way of regulating how ceasefire agreements are negotiated and their knock-on effects, always in the hope of providing civilians with greater protection during times of armed conflict.

\footnotetext{
${ }^{103}$ ICRC definition of a 'truce', available at casebook.icrc.org/glossary/truce.
} 